\title{
Comparison on the Properties of Various Alternative Materials for Replacing River Sand in Structural Elements
}

\author{
Theivabharathi $^{1}$, Manjuladevi ${ }^{2}$, S.Rajalakshmi ${ }^{3}$ and A.Vishnu ${ }^{4}$ \\ ${ }^{1 \& 2}$ UG Student, ${ }^{3 \& 4}$ Assistant Professor, \\ Department of Civil Engineering, Kumaraguru College of Technology, Coimbatore, Tamil Nadu, India \\ E-Mail:theiva.15ce@kct.ac.in
}

\begin{abstract}
River sand is a non-renewable source of material which we have been utilizing it in construction for years. In this paper replacement of natural river sand by various byproducts and waste materials obtained from different sources have been taken for the study to compare their properties with that of the river sand. The alternative materials considered for the study were M-sand, Eco sand, Copper slag, crushed glass, quarry dust, foundry sand, biomedical waste ash. Some of the materials have been already tested and the optimum percentage of usage in concrete has been determined. But the comparison of their properties with that of the river sand with $100 \%$ replacement have been carried out for the study in order to check their potential to act as fine aggregate in concrete or construction industry. The tests performed were sieve analysis, specific gravity, moisture contentand compressive strength of cement mortar cubes.The test results obtained would help us in projecting a newer dimension in use of these materials in structural elements too. If it's proven successful, thenwe would be able to implement it in large scale which would help us to revolutionize the construction industry by economizing the construction cost and enabling us to conserve the natural resources.
\end{abstract}

Keywords: Conserve, Economize, Copper slag, M-sand

\section{INTRODUCTION}

River Sand being animportant filler material is used as the fine aggregate in the manufacture of concrete. Since the source of river sand being a depleting inversely to its demand, the construction industry is in need of a finding a best alternative source for replacing the river sand in concrete. In addition to the demand, increased extraction of natural sand from river beds causes many problems like lose in water retaining sand, deepening of the river courses and causing bank slides. With the aim of identifying the alternative material to river sand for concrete making, waste and abundant materials like Foundry Sand, Manufactured Sand (M-sand), and Eco Sand, Bio Medical Waste, Copper slag, Glass and Quarry dust were chosen for the study. Various tests were performed to compare their results with that of river sand.

\section{MATERIALS USED}

A.Cement:

Ordinary Portland cement (OPC)-OPC 53 grade is used for the study.

\section{B.Fine Aggregate}

1. Foundry Sand:Foundry Sand is high quality silica sand obtained as a waste product from ferrous and non-ferrous metal casting industries. These are used an alternative material to the river sand and studied for their properties [6].

2. Copper Slag: Copper slag is a waste by-product obtained during the smelting and refining of copperduring its process of manufacture. To produce every ton of copper, approximately 2.2-3.0 tons copper slag is generated as a byproduct material. If used in concrete, it will help in reducing the cost of concrete, and minimizing air pollution problems [2].

3. M-Sand: Manufactured sand is produced by crushing boulders or stones and rocks in desired size and grade by suitable method[1]. This material is also chosen for study and compared with that of river sand.

4. Eco Sand: Eco sand is a by-product obtained from cement manufacturing process mainly cement industries those use silica as a raw material. They are very fine particles which can be used to increases efficiency in concrete. Its micro-filling effect reduces pores in concretes and provides better moisture resistivity and thus durability. It has more consistent grading than many extracted aggregates.

5. Quarry Dust: Quarry dust is a waste non-renewable byproduct which is formed in the processing of granite stone that is broken down into a coarse aggregate of different sizes. The dust is collected from the nearest source as a raw material without any processing of dust from the quarry.

6. Bio Medical Waste: Bio-Medical Waste (BMW) is the waste solids, liquids, sharps and laboratory waste that are potentially infectious or dangerous. The BMW produced from hospitals depend upon a number of factors such as disposal methods, type of hospital, occupancy of hospital, specialization of hospital, ratio of reusable items, availability of resources. The incinerated biomedical waste is attempted to use as a replacement material for natural river sand in concrete.

7. Glass Powder: Waste glasses are accumulated from various sources was powdered by squashing waste glass pieces in a cone crusher. Glass has limited life span and 
after use it is either stock piled or sent to landfills. It's used as an alternative material to fine aggregate in [6] \& [7].

\section{TESTING OF MATERIALS}

Before using a material as a replacement for fine aggregate it's required to test the properties of the chosen materials and compare that with that of natural sand used in concrete. Various tests as per [9] \& [10] were performed on these chosen materials were specific gravity, water absorption, bulk density, void ratio, bulking, sieve analysis and mechanical property testing by casting cement mortar cubes.

\section{A.Specific Gravity}

The specific gravity is the ratio of the density of a substance to the density of a reference substance.The specific gravity of the materials was done using pycnometer bottle. The test results were mentioned in Table.1

\section{B.Water Absorption}

Oven dry method is the most accurate method of determining the water content and is therefore used in the laboratory. The water content of a moist soil sample is done by pycnometer. The specimen should be dried in the oven to constant mass indicated between two consecutive mass of the container with the dried specimen taken at intervals after initial drying, being a maximum of 0.1 per cent of the original mass of the soil specimen. The test procedure followed by Indianstandard (IS: 2720-1973).The number of opening s per inch is equal to the square if the number of the sieve. In Indian standard (IS :460-1962) the sieve are designed by the size of the aperture in $\mathrm{mm}$. Sieve size $4.75 \mathrm{~mm}, 2.36 \mathrm{~mm}, 1.18 \mathrm{~mm}, 0.6 \mathrm{~mm}, 0.3 \mathrm{~mm}, 0.15 \mathrm{~mm}$, $0.075 \mathrm{~mm}$ and pan for fine aggregate.

\section{Bulk density and voids}

The bulk density is the weight of material in a given volume, in $\mathrm{kg} / \mathrm{l}$. The bulk density of an aggregate is affected by several factors, including the amount of moisture present and the amount of effort introduced in filling the measures.

\section{Bulking}

If the sand is measured by loose volume, it is necessary in such a case to increase the measured volume of the sand.

\section{TEST RESULT OF MATERIALS}

\section{A. Specific gravity}

The aggregate shall be placed in the pycnometer which shall be filled with distilled water. The pycnometer shall be topped up with distilled water to remove any froth from the surface and so thatthe surface of the water in the hole is flat. The pycnometer shall bedried on the outside and weighed (weight B).The contents of the pycnometer shall be emptied into the tray, carebeing taken to ensure that all the aggregate is transferred. Thepycnometer shall be refilled with distilled water to the same level asbefore, dried on the outside and weighed (weight $\mathrm{C}$ ). The differencein the temperature of the water in the pycnometer during the first andsecond weightings shall not exceed $2^{\circ} \mathrm{C}$. The water shall then be carefully drained from the sample by decantation through a filter paper and any material retained returned tothe sample. The sample shall be placed in the oven in the tray at a temperature of 100 to $110^{\circ} \mathrm{C}$ for $24 \mathrm{f} \mathrm{l} / 2$ hours, during which period it shall be stirred occasionally to facilitate drying. It shall be cooled in the air-tight container and weighed (weightD).

TABLE I SPECIFIC GRAVITY OF MATERIALS

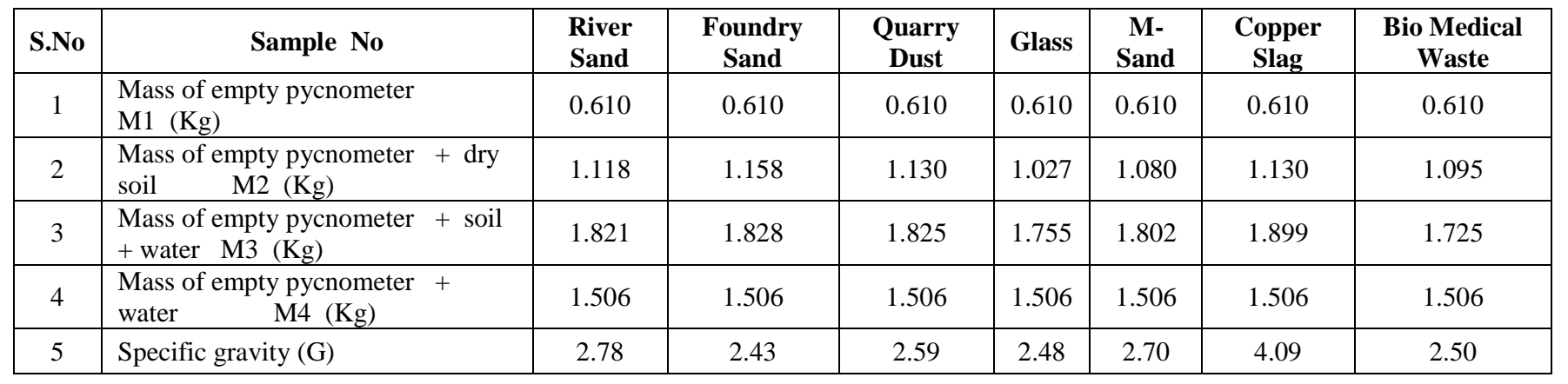

\section{B. Bulk Density and Voids}

Condition of Specimen: Thetest shall normally be carried out on dry material when determining the voids, but when bulking tests are required material must be tested with a given percentage of moisture.

\section{Water Absorption}

The surface water content may be determined either by weight or by volume. In each case the test shall be made at a temperature range of 22 to $32^{\circ} \mathrm{C}$. The container shall be filled up to the mark with water and the weight in grams determined. The container shall be emptied enough water shall be placed in the container to cover the sample, after which the sample of fine aggregate shall be introduced into the container and the entrained air removed. The container shall then be filled to the original mark and the weight in gram is noted. 


\section{Sieve Analysis}

The sample shall be brought to an air-dry condition before weighing and sieving. This may be achieved either by drying at room temperature or by heating at a temperature of 100 to $110^{\circ} \mathrm{C}$. The air-dried sample shall be weighed and sieved successively on the starting with the largest sieve at the top.

\section{E. Mechanical Properties}

All the cement cubes are tested in saturation condition after drying, the surface of the specimen containing no moisture in it. For each mix proportions, three cubes are tested at 7 days, using compression testing machine of $2000 \mathrm{kN}$ capacity. The tests are carried out at a uniform rate stress level with the specimen properly placed and centered in the testing machine. Loading is applied gradually with the help of hydraulic pumps until the dial gauge reading get reverses its direction of motion. The reversal of needle indicates the total failure of the specimen. The dial gauge reading is noted at the instant of failure, which is ultimate failure load of specimen. The main objective of this experimentation is to find out hardened properties of cement mortar by the effect of $100 \%$ replacement of natural river sand by manufactured sand, foundry sand, quarry dust, glass, copper slag, bio medical waste. The experimental work includes the casting, curing and testing of specimens. The test was carried out on 14 days.

TABLE II BULKING OF SANDS

\begin{tabular}{|l|c|c|c|c|c|c|c|}
\hline \multicolumn{1}{|c|}{ Sample No } & $\begin{array}{c}\text { River } \\
\text { Sand }\end{array}$ & $\begin{array}{c}\text { Foundry } \\
\text { Sand }\end{array}$ & $\begin{array}{c}\text { Quarry } \\
\text { Dust }\end{array}$ & Glass & M-Sand & $\begin{array}{c}\text { Copper } \\
\text { Slag }\end{array}$ & $\begin{array}{c}\text { Bio Medical } \\
\text { Waste }\end{array}$ \\
\hline $\begin{array}{l}\text { Weight of the sample } \\
\text { W1(kg) }\end{array}$ & 250 & 250 & 250 & 250 & 250 & 250 & 250 \\
\hline $\begin{array}{l}\text { Dry weight of the sample } \\
\text { W2(kg) }\end{array}$ & 249 & 244 & 245 & 249.5 & 246 & 248 & 244.3 \\
\hline $\begin{array}{l}\text { Water content } \\
\text { W }\end{array}$ & $0.3 \%$ & $2.8 \%$ & $2 \%$ & $0.2 \%$ & $1.6 \%$ & $0.8 \%$ & $2.3 \%$ \\
\hline
\end{tabular}

TABLE III SIEVE ANALYSIS FOR RIVER SAND

\begin{tabular}{|c|c|c|c|c|c|c|}
\hline S.No & Sieve Size & $\begin{array}{c}\text { Weight } \\
\text { Retained (Gm) }\end{array}$ & $\begin{array}{c}\text { Cumulative } \\
\text { Weight Retained }\end{array}$ & $\begin{array}{c}\text { \% Weight } \\
\text { Retained (\%) }\end{array}$ & $\begin{array}{c}\text { Cumulative \% } \\
\text { Weight Retained (A) }\end{array}$ & $\begin{array}{c}\text { \% Of Finer } \\
\text { (100-A) }\end{array}$ \\
\hline 1 & $4.75 \mathrm{~mm}$ & 0020 & 0020 & 02.00 & 02.00 & 98.00 \\
\hline 2 & $2.36 \mathrm{~mm}$ & 0118 & 0138 & 11.80 & 13.80 & 86.20 \\
\hline 3 & $1.18 \mathrm{~mm}$ & 0240 & 0378 & 24.00 & 37.80 & 62.20 \\
\hline 4 & $600 \mathrm{~mm}$ & 0300 & 0678 & 30.00 & 67.80 & 32.20 \\
\hline 5 & $300 \mathrm{~mm}$ & 0246 & 0924 & 24.60 & 92.4 & 07.60 \\
\hline 6 & $150 \mathrm{~mm}$ & 0044 & 0968 & 04.40 & 96.8 & 03.20 \\
\hline 7 & $75 \mathrm{~mm}$ & 0024 & 0992 & 02.40 & 99.2 & 00.80 \\
\hline 8 & Pan & 0008 & 1000 & 00.80 & 100.00 & 00.00 \\
\hline
\end{tabular}

TABLE IV COMPRESSIVE STRENGTH FOR DIFFERENT TYPES OF SANDS

\begin{tabular}{|c|c|c|}
\hline SI.No & Sand Name & $\begin{array}{c}\text { Compressive } \\
\text { Strength( } \mathbf{~} / \mathbf{m m}^{\mathbf{2}} \text { ) (Days) }\end{array}$ \\
\hline 1 & River sand & 16.4 \\
\hline 2 & M - Sand & 14.9 \\
\hline 3 & Quarry sand & 14.63 \\
\hline 4 & Bio medical waste & 12.33 \\
\hline 5 & Copper slag & 16.29 \\
\hline 6 & Glass & 8.36 \\
\hline 7 & Foundry sand & 5.33 \\
\hline
\end{tabular}

COMPARATIVE STUDY OF RIVER SAND WITH OTHER ALTERNATIVE MATERIALS (14 DAYS)

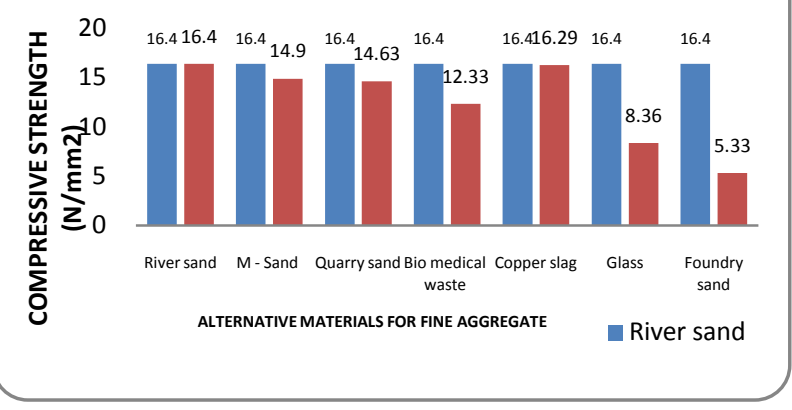

Fig 1.Compressive strength of cement mortar 


\section{RESULTS AND CONCLUSION}

The comparative chart shown above can be used to determine the potential of various alternative materials for construction of buildings. From the above test data, it is found that the compressive strength of copper slag is much equivalent to that of the river sand during 14 day of testing. It proves to be the best alternative material for replacement of river rand in cement mortar mixes. The other alternative materials that gives good results were m-sand and quarry dust particles for which the compressive strength values is slightly less compared to that of the river sand. Higher of river sand, can be alternatively supplied with the alternative waste materials like copper slag, m-sand and quarry dust. This also reduces environmental pollution.Hence they can be used in cement mortars which are used for plastering works, guniting,etc. The future scope of this work could be extended to the use of the alternative materials identification in concrete mixes which can be helpful to identify their potential and behavioural change in concrete.

\section{REFERENCES}

[1] B. P Hudson, "Manufactured Sand for concrete",The Indian concrete Journal, pp. 237-240,1997.

[2] AS Alnuaimi, "Effects of Copper Slag as a Replacement for Fine Aggregate on the Behavior and Ultimate Strength of Reinforced Concrete Slender Columns", Sultan Qaboos University,Vol.9,pp.90102, 2012.

[3] Antonio M. Arino and BarzinMobasher, "Effect of Ground Copper Slag on Strength and Toughness of Cementitious Mixes", ACI Materials Journal,Vol.96, No.1,pp.68-74, 1999.

[4] Tarun R. Naik, Viral M. Patel, Dhaval M. Parikh and Mathew P. Tharaniyil, “Utilisation of used foundry sand in concrete”, Journal of Materials in Civil Engineering, Vol. 6, No. 2, 1994.

[5] P.S. Eknath andD.B. Desai, "Application of foundry waste sand in manufacture of concrete",IOSR journal of Mechanical and Civil Engineering, pp. 43-48, 2009.

[6] Gunalaan, Vasudevan, "Using waste glass powder in concrete mix", American Journal of Engnieering Research, ISSN: 2320-0936, Vol. 2, No. 12, pp. 175-181, 2013.

[7] C.D Arun Kumar and K.Sakthimurugan, "Study of waste glass powder as pozzolanic material in concrete", Journal Built Expressions, Vol. 2, No. 5, 2013.

[8] IS 383: 1970, Indian standards specification for coarse and fine aggregate from natural source for concrete.

[9] IS 2386: 1963, (Part I to Part VIII) Indian standards methods of test for aggregate for concrete.

[10] SP 23: 1982, Indian standards handbook on concrete mixes. 